\title{
Stable isotopic evidence for land use patterns in the Middle Euphrates Valley, Syria
}

\section{Arkadiusz Sołtysiak ${ }^{1}$ (iD) | Holger Schutkowski²}

\author{
${ }^{1}$ Department of Bioarchaeology, Institute of \\ Archaeology, University of Warsaw, \\ ul. Krakowskie Przedmieście 26/28, \\ Warszawa 00-927, Poland \\ ${ }^{2}$ Faculty of Science and Technology, \\ Department of Archaeology, Anthropology \\ 9 and Forensic Science, Bournemouth \\ University, Fern Barrow, Poole, Dorset \\ BH12 5BB, United Kingdom \\ Correspondence \\ Arkadiusz Sołtysiak, Department of \\ Bioarchaeology, Institute of Archaeology, \\ 14 University of Warsaw, Poland, ul. \\ 15 Krakowskie Przedmieście 26/28, \\ 00-927 Warszawa, Poland. \\ 6 Email: a.soltysiak@uw.edu.pl \\ Funding information \\ Polish National Science Centre (Narodowe \\ Centrum Nauki), Grant Number: 2012/06/ \\ $\mathrm{M} / \mathrm{HS} 3 / 00272$
}

\begin{abstract}
Objectives: Stable carbon and nitrogen isotope ratios $\left(\mathrm{d}^{13} \mathrm{C}\right.$ and $\left.\mathrm{d}^{15} \mathrm{~N}\right)$ were used to reconstruct the history of subsistence strategies in the middle Euphrates valley, NE Syria, in six temporal subsets dating from the Early Bronze Age (c. 2300 BCE) to the Modern period (19th/20th century CE). The study aims to demonstrate that changes in political and social organization over time, for which the archaeological record suggests different goals of land use and modes of production, register through dietary patterns that are reflected in isotopic data.

Materials and methods: 173 dentin samples were taken from human individuals buried at three sites (Tell Ashara, Tell Masaikh and Gebel Mashtale) together with 15 animal bone samples. Distribution of the $d^{13} \mathrm{C}$ and $d^{15} \mathrm{~N}$ values in collagen was interpreted in diachronic perspective, and with regard to lifetime shifts between childhood and adolescence.

Results: Diachronically, isotope signatures indicate a clear decrease in $\mathrm{d}^{15} \mathrm{~N}$ values accompanied by a small shift in $d^{13} \mathrm{C}$ values between the Old Babylonian (c. 1800-1600 BCE) and the NeoAssyrian (c. 850-600 BCE) subsets. A major shift in $\mathrm{d}^{13} \mathrm{C}$ values occurred between the Early Islamic (c. 600-1200 CE) and Modern (c. 1800-1950) periods. Ontogenetic changes only occur in a few individuals, but these suggest change of residence between childhood and adolescence.

Discussion: The depletion in ${ }^{15} \mathrm{~N}$ from the Neo-Assyrian period onwards is best explained in terms of a shift from intensive to extensive farming, triggered by the fall of regional city-states after the Old Babylonian period and the formation of large supra-regional polities in the Neo-Assyrian period and later. The enrichment in ${ }^{13} \mathrm{C}$ during the Modern period was most likely the effect of more widely utilizing the dry steppes, abundant in $\mathrm{C}_{4}$ plants, as pasture.
\end{abstract}

KEYW ORDS

carbon isotopes, diet, Mesopotamia, nitrogen isotopes, subsistence strategies

\section{1 | INTRODUCTION}




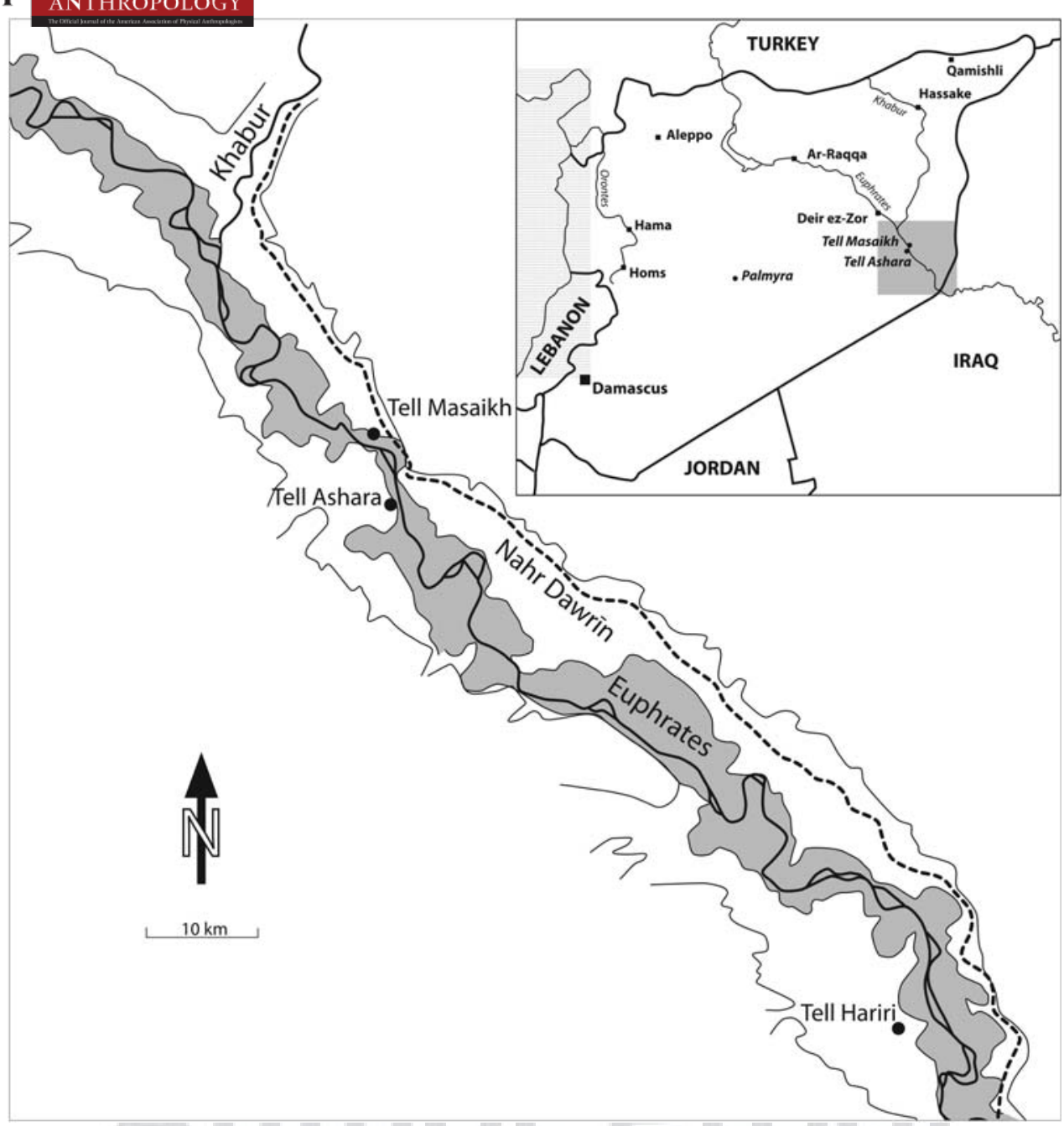

FIGURE 1 Map of the Euphrates valley between the Khabur confluence and Tell Hariri, showing the locations of major sites mentioned in the paper

(see Sołtysiak \& Bialon, 2013 for the population history of this region). Isotopic data are used to trace the temporal changes in the interplay between subsistence strategies that may have been adopted separately or jointly in the region. Results of previous studies suggest a dichotomy between local and regional modes of production, namely farming based on higher water tables near the river, artificial irrigation, import of grains from dry farming zones, and herding inside the valley or outside in the dry steppe (see below). The political structures, independent smaller kingdoms of the Bronze Age, or supra-regional empires during the Iron Age, effected the implementation of such different land use strategies over time, for example, efforts to intensify agricultural production during the Bronze Age, as opposed to extending agriculture to larger areas of available and controlled land during the Iron Age.

We hypothesize that the ensuing significant regional socioeconomic developments are reflected in diachronic patterns of dietary and subsistence change. This will provide both novel and corroborating proxy evidence of societal change, for which the archaeological and textual sources alone cannot offer comprehensive explanation. Adjustments to agricultural production in response to availability of land and resources facilitated the construction of artificial irrigation structures to increase water availability, or the exploitation of the dry steppe more 70 abundant in $\mathrm{C}_{4}$ grasses than the vegetation cover in the valley. Subsist- 71 ence data directly ascertained from the populations that inhabited the 72 region can thus test independently whether the political goals of 73 changing modes of food production in support of regional and supra- 74 regional polity formation find their expression in dietary information, as 75 the concomitant small and larger scale societal changes can be 76 expected to register in isotopic data. We also aim to trace these dia- 77 chronic observations into modern times by incorporating data from 78 contemporary Bedouin cemetery for comparison. Findings are dis- 79 cussed in the bioarchaeological context of the respective time periods. 80

\section{1 | Ecological settings}

81

The lower middle Euphrates valley (Figure 1 ) is not a very favourable 8 F1 place for agriculture. The average annual precipitation is too low (c. 83 $140 \mathrm{~mm}$ ) for dry farming and the valley is too deep and narrow for 84 extensive irrigation, as opposed to the alluvial plain of southern Meso- 85 potamia. For that reason, the textual evidence from the 3rd millennium 86 BCE onwards shows that the local population consisted of relatively 87 
low number of settled farmers using narrow strips of arable land in the floodplains along the river bed and semi-nomadic pastoralists who operated with their ovicaprid herds in the dry steppes, sometimes far away from the Euphrates (Lyonnet, 2001, 2009). Such a dimorphic society with strong ties between two groups exercising different subsistence strategies is well documented especially in the early 2 nd millennium BCE by the abundant cuneiform archives from Mari (Fleming, 2009; Pitard, 1996; Rowton, 1974). Trade was also important in the local economy, at least in those periods when the exchange of goods between southern Mesopotamia and Anatolia or the Levant was common and well organized (Klengel, 1983; Leemans, 1977; Zawadzki, 2008). However, the balance between plant- and animal-based food may be assumed to have been relatively stable in the middle Euphrates valley. Plant cultivation was less dependent on precipitation compared to areas further north (Wilkinson, 1997), nor endangered by soil salinization as in the southern alluvium (Artzy \& Hillel, 1988). The efficiency of pastoralism was secured by abundant dry steppes.

Archaeobotanical research shows that from the 3rd millennium BCE to the 1st millennium CE the most important crops, as in other semi-arid areas of the Near East, were barley and wheat, with only a minor share of lentils or other legumes (Riehl, 2009; Samuel, 2001). The proportions of domesticated animals represented by bone remains are quite stable with $60-80 \%$ ovicaprids, and $20-40 \%$ cattle from the late 3rd millennium BCE onwards, except during the earliest phases of occupation at Tell Ashara (Early Dynastic and Akkadian periods, c 2700-2300 BCE), which displays a greater number of ovicaprids. Most importantly, the remains of omnivorous animals such as pigs were absent or very infrequent in bone assemblages from all chronological contexts (Grézak, 2015). Similarly, the economy of modern Bedouin tribes before their continuous sedentarization during the 20th century CE almost exclusively relied on nomadic ovicaprid herding (Bahhady, 1981)

\section{2 | Artificial irrigation and temporal changes in} agricultural strategies

The scale of artificial irrigation in the middle Euphrates valley is a highly discussed topic, and it usually focuses on the canal known as Nahr Dawrīn, located on the left (eastern) upper river terraces of the lower Khabur and middle Euphrates. Its total length is about $120 \mathrm{~km}$ and its width varies from eight to eleven meters (Figure 1), with large portions of this huge earthwork still clearly visible in the landscape (Figure 2). Both the dating and the function of Nahr Dawrīn are debated and the only commonly accepted fact is that the canal was used in the Early Islamic period, at least in the 7th/8th century CE, and was deserted before the 11th century as a consequence of political instability in the region.

Due to repeated conservation and repair work in antiquity, the construction of the canal cannot be dated through any archaeological method, and the textual evidence is sparse and unclear. For that reason, suggested dates vary by more than 3000 years (cf. Lafont, 2009). According to Margueron (2004:76-79), the canal was dug in the Early Bronze Age to secure a safer navigation on the major trade route along

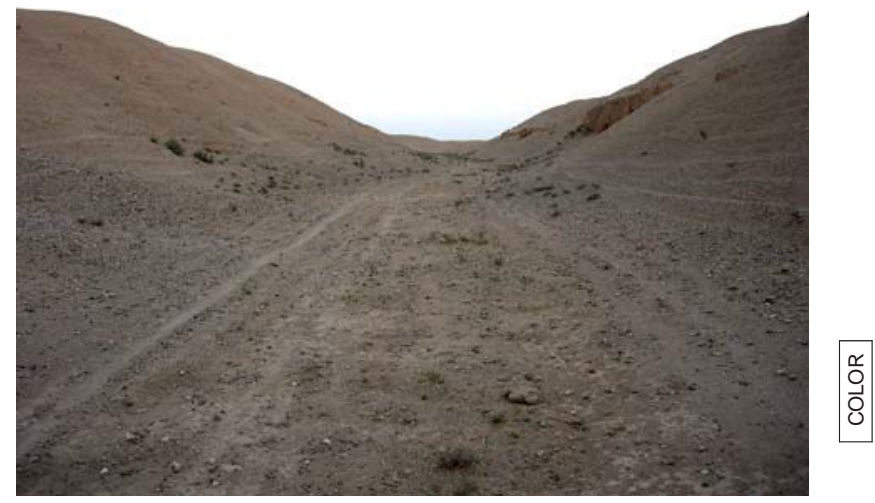

FIGURE 2 Well preserved section of the Nahr Dawrīn canal near Tell Masaikh

the Euphrates and Khabur (see also Geyer \& Monchambert, 2003:212- 139 213). Most other authors, however, point out that the location of the 140 canal suggests gravity irrigation, but indications as to when it may have 141 been constructed range widely, from Old Babylonian (Durand, 142 1997:580), through the Middle Assyrian or Neo-Assyrian period 143 (Durand, 2002; K白hne, 1995; Kজ氏hne \& Becker, 1991; Masetti-Rouault, 144 2008, 2010) to Early Islamic times (Berthier, 2001), with only limited 145 evidence to support these proposals.

Arguably, the existence of a large canal structure would provide a 147 tangible link to the known efforts of the Neo-Assyrian and later 148 empires to expand agricultural production on a large scale. Irrigation of 149 a large part of the river valley could thus increase settlement density in 150 the areas that were turned into agricultural land, but reported settle- 151 ment patterns in the lower middle Euphrates valley are inconsistent 152 and only suggest relative stability from the Early (EBA, c. 3000-2100 153 $\mathrm{BCE})$ to Middle Bronze Age (MBA, c. 2100-1500 BCE), with a decline 154 by the Late Bronze Age (LBA, c. 1500-1200 BCE) and some recovery 155 in the Neo-Assyrian period (c. 850-600 BCE). Finally, after a decrease 156 in settlement density in the Achaemenian period (c. 550-330 BCE), the 157 number of sites gradually increased to an absolute peak in the Early 158 Islamic period (Geyer \& Monchambert, 1987; Simpson, 1984). 159

However, there is some evidence for a relationship between set- 160 tlement pattern and the course of Nahr Dawrīn, mainly for the Neo- 161 Assyrian (Masetti-Rouault, 2010) and Early Islamic periods (Berthier, 162 2001). In the former period, Kar-Assurnasirpal (modern Tell Masaikh), 163 the largest known site on the left bank of the Euphrates, was estab- 164 lished as the capital city of the Assyrian province of Rasappa. Since the 165 Assyrians were interested in increasing agricultural production, the con- 166 struction, reconstruction or extension of Nahr Dawrīn may have been 167 an element of their policy (Masetti-Rouault, 2008, 2010).

Possible archaeobotanical evidence of irrigation would entail a shift 169 from more to less drought resistant crops and the presence of weed 170 species that grow in humid conditions. However, the dominant crop in 171 all periods under investigation was barley, supplemented by small 172 quantities of wheat, accompanied by some broomcorn millet from the 173 Neo-Assyrian period onwards. From this time period, grass pea 174 
(Lathyrus sativus) is present at Tell Masaikh, and its combination with millet and barley supports prevailing dry conditions associated with agriculture (Kubiak-Martens, 2013).

On the other hand, small-scale irrigation was always possible in the floodplain of the Euphrates including its oxbow marshes and, although agriculture based on such irrigation was risky due to the unpredictable seasonal amplitude of the river water table, intensive cultivation of areas along the river may have been exercised since the mid-4th millennium BCE (Masetti-Rouault, 2008). For example, there is clear evidence of small irrigation network in the neighborhood of Tell Hariri/Mari, dated to the mid-3rd millennium BCE (Geyer \& Monchambert, 2003).

Archaeobotanical data from Tell Ashara and Tell Masaikh include some weed species that indicate good moisture conditions at least since the 3rd millennium (Kubiak-Martens, 2015). During the NeoAssyrian (9th to 7th century BCE) and later periods these weeds, for example, amaranth (Amaranthus sp.) and Bermuda grass (Cynodon dactylon) known to grow especially on the banks of canals, were quite common. In the Neo-Assyrian samples from Tell Masaikh there are also several rare crops that need good watering, such as coriander (Coriandrum sativum), celery (Apium graveolens), cumin (Cuminum cyminum), possibly also dill (Anethum graveolens) and cultivated grape (Vitis vinifera) (Kubiak-Martens, 2013). However, they were recovered from the governor's palace and, therefore, may not be representative for the general agriculture of that period. Late Roman samples as well included some more water-demanding species, such as free-threshing wheat grapes, figs (Ficus carica), and melon (Cucumis melo) (Kubiak-Martens, 2015).

Therefore, the archaeobotanical evidence is ambiguous. But also the assemblages of animal bones reveal only minor differences in the proportions of domesticated animals. In all periods sheep and goats were the predominant species (from $85 \%$ during the 3rd millennium BCE to $60 \%$ in the Islamic period), but in the Neo-Assyrian period and especially in the Islamic period (but not in the Late Roman period) the share of cattle bones clearly increased. Pigs were present only in the Neo-Assyrian and Late Roman periods when they represented c. $5 \%$ of the entire assemblage (Grezak, 2015). Cattle and pigs need much more water than ovicaprids, but a direct comparison of species representation is difficult as only the number of identified specimens (NISP) is available and moreover the dominance of ovicaprids - in concert with a predilection for barley — may be a cultural rather than ecological choice. Especially the absence of pigs in the Islamic period was likely related to their cultural perception as impure animals (cf. Kassam \& Robinson, 2013)

The textual evidence is also ambiguous. Several sources from Mari mention irrigation works that were undertaken under the rule of Yahdun-Lim (c. 1810-1794 BCE) and his son Zimri-Lim (c. 1775-1761 BCE). Apart from accounts of two canals called Hubur and IsimYahdun-Lim, located most likely on the right bank of the Euphrates north of the Khabur confluence, there is also information provided in a letter by the governor Yaqqim-Addu that another canal transported the waters of the Khabur and was an important part of the irrigation system (Durand, 1997:580; Heimpel, 2003; Viollet, 2004:56). However, neither the length nor a more precise location of this canal are clearly described here or in other contemporary documents. No known texts 228 refer explicitly to any irrigation canals during the Neo-Assyrian period 229 (Masetti-Rouault, 2010).

A few hundred years later, Xenophon mentiones the river Maskas 231 (Anabasis 1.5.4), perhaps subsequently referred to by Ptolemy as Sao- 232 coras (Geographia 5.18.3), which has been located as a left-hand tribu- 233 tary of the Euphrates 35 parasangs (about 100-140 km) below the 234 confluence of the Khabur (Lempriere, 1836:199; Ainsworth, 235 1888:432-433). According to Xenophon, the river Maskas surrounded 236 a large deserted city named Korsote, which may be identified as one of 237 two modern archaeological sites, either Baghouz or ed-Diniyye (Bar- 238 nett, 1963:3-5). On the other hand, there is also a possibility that Mas- 239 kas and Saocoras were nothing but ancient names of the Khabur itself 240 (cf. Gawlikowski, 1992).

Islamic sources explicitly mention one canal in the area between 242 Deir ez-Zor and Al Bukamal, referred to as Nahr Sa'id after its creator, 243 prince Sa'id ben 'Abd al-Malik in the early 8th century CE. Its location 244 is not completely fixed, but it most likely used waterwheels to irrigate a 245 relatively large right bank floodplain of the Euphrates north of the Kha- 246 bur confluence, in the approximate location as the earlier canals Hubur 247 and Isim-Yahdun-Lim (Genequand, 2009; Rousset, 2001). However, 248 small archaeological test trenches in Nahr Dawrīn revealed Early Islamic 249 pottery and the distribution of 26 small sites along the canal dated to 250 the Umayyad period (661-750 CE) suggests that Nahr Dawrīn was 251 used in the 7th/8th century CE (Berthier, 2001; Hont, 2005:208), and 252 likely was abandoned not much later. Thus, the last date for possible 253 irrigation using the Nahr Dawrīn may be safely estimated between the 254 8th and 10th century CE.

Abundant archives from the royal palace of Mari, dated to $18^{\text {th }}$ century 257 $\mathrm{BCE}$, show a specific social organization with urban dwellers of the 258 major cities (Mari and Terqa), farmers engaged in plant cultivation along 259 the river and small-scale stationary animal husbandry, as well as semi- 260 nomadic pastoralists that operated in the dry steppes beyond the upper 261 terrace. These mobile herders were tied to the settled population by 262 mutual exchange of various products, but also by kinship (Liverani, 263 1997; Rowton, 1974, 1977).

While state authorities sought to keep mobile herders under con- 265 trol (cf. Bonneterre, 1995), they nevertheless occasionally invaded 266 lands under cultivation and disrupted agricultural production. However, 267 for most of the time, co-existence of herders and settled population 268 was peaceful and the network of relation between two socioeconomic 269 entities operating in different ecological zones has been labeled as 270 dimorphic society (Rowton, 1977).

It is unclear whether such a close relationship between mobile pas- 272 toralists and farmers was typical only for the kingdom of Mari during 273 the Early and Middle Bronze Age, or whether it was present also in 274 later periods. The social and economic crisis of the 12th century BCE 275 forced herders to become more mobile and previous kingdoms of the 276 Near East based on agriculture collapsed (Neumann \& Parpola, 1987). 277 It is likely that during that time some farmers joined Aramean tribes of 278 
herders, but in general during the beginning of the Iron Age the mobile herders were perceived as a major threat by urban dwellers. In times of the Neo-Assyrian Empire (9th-7th century BCE) the agricultural potential of northern Mesopotamia was restored and the state was powerfu enough to strictly control herders (Sołtysiak, 2016). However, in later periods some autonomy of Aramean and Arab nomadic tribes was attested and the mobility of herdsmen was increased due to domestication of camels (Rosen \& Saidel, 2010).

The most rapid and drastic change in the history of North Mesopotamia was caused by the invasion of Mongols in the second half of the 13th century CE. They destroyed many cities, killed large parts of the local population, and devastated lands under agriculture. After their raids and other conflicts in the area, the part of the Euphrates valley not suitable for dry farming was largely abandoned and eventually taken by Bedouin tribes that moved in from the Arabian Peninsula during the 17th century. In contrast to previous periods, Bedouins operated mainly in the dry steppe, and had much lower interaction with the scarce remaining permanent sites along the valley (Raswan, 1930).

\subsection{Stable nitrogen and carbon isotopes: The model}

The general principles underlying the representation of dietary signals by stable isotope values of carbon and nitrogen in past populations are established and the processes of fractionation and trophic level spacing well understood (e.g., Lee-Thorp, 2008 for overviews; Katzenberg, 2008). In the context of the present study, several more specific aspects are particularly pertinent and will be addressed for their relevance as outlined above.

Archaeological populations of the Old World are frequently associated with a subsistence strategy that provided them with a mainly $\mathrm{C}_{3}$ based terrestrial diet consisting of varying proportions of plant and animal-derived foodstuffs. Ecological circumstances and cultural choices govern the dietary mix that is eventually reflected in the isotope values of human bone and teeth. In areas characterized by low precipitation, such as the middle Euphrates valley, crops that are less demanding are expected to form the main-stay of plant matter supply, but irrigation broadens the range of cultivated food items to dietary staples that may be grown or consumed. In addition, there were certain time periods when more arid-adapted $\mathrm{C}_{4}$ crops, such as broomcorn millet may have been grown. $\mathrm{C}_{4}$ crops follow a biochemical pathway that reflects adaptation to an arid climate, where there is pronounced discrimination against ${ }^{13} \mathrm{C}$, whose incorporation into the diet would result in more positive $\mathrm{d}^{13} \mathrm{C}$ values of the human end user (Nesbitt \& Summers, 1988). However, even if present, millets were never an important part of human or animal diet in the middle Euphrates area (cf. Kubiak-Martens, 2015). Diversification of agricultural strategies, for example the expansion of pastoral activities into the dry steppe, exposes livestock to a variety of $\mathrm{C}_{3}$ and $\mathrm{C}_{4}$ shrubs and grasses. When humans subsequently consume these animals or their products, the $\mathrm{C}_{4}$ component would result in more positive $\mathrm{d}^{13} \mathrm{C}$ values in humans as well and thereby indicate an adaptation in subsistence activities.

Nitrogen stable isotope values largely reflect consumption of animal-derived protein in temperate climates (Hedges \& Reynard,
2007). In arid regions, elevated $d^{15} \mathrm{~N}$ values were long thought to be a 330 result of water stress, either through consumption of water-stressed 331 animals or as a direct effect on humans, with the underlying mechanism 332 relating to the increased excretion of urea, which is ${ }^{14} \mathrm{~N}$-depleted rela- 333 tive to the diet and thus ${ }^{15} \mathrm{~N}$ is enriched in the body (Ambrose \& 334 DeNiro, 1987). Isotope data from controlled feeding experiments 335 (Ambrose, 1983) and, especially, herbivores from arid areas (Hartmann, 336 2011) now suggest that $d^{15} \mathrm{~N}$ values are rather determined by the iso- 337 topic composition of their diet.

In agricultural systems where intensive cultivation is maintained by 339 high levels of manuring, $\mathrm{d}^{15} \mathrm{~N}$ values are likely to be elevated (cf. Fraser 340 et al., 2011; Styring et al., 2016) and this effect may be high enough to 341 differentiate between intensive (small area, high manuring) and exten- 342 sive (large area, low manuring) agriculture in North Mesopotamia (Styr- 343 ing et al., 2017). In the specific case of the middle Euphrates valley, 344 transition from more intensive to more extensive agriculture may have 345 been enabled mainly by introduction of the large-scale irrigation system 346 that dramatically increased the area suitable for plant cultivation and at 347 the same time decreased pastures within the valley.

\section{2 | MATERIALS}

Human and animal remains used for the present study were excavated 350 at three archaeological sites located c. $70 \mathrm{~km}$ south of Deir ez-Zor (Fig- 351 ure 1). Tell Ashara (ancient Terqa) was a major city during the MBA and 352 LBA, and the capital city of the Khana kingdom that followed the 353 destruction of Mari by Babylonians in the mid-18th century BCE. Sev- 354 eral burials dating to this period were found in the domestic areas. Dur- 355 ing 19th and early 20th century, local Bedouin tribes used the top of 356 the ancient site as a regular cemetery.

Tell Masaikh (ancient Kar-Assurnasirpal) was a small settlement 358 during the Early Chalcolithic and in the MBA, and a large regular town 359 during the Neo-Assyrian period. A dozen burials were recovered here 360 in domestic contexts. During Classical Antiquity and later it was also 361 used as a cemetery. Gebel Mashtale is a much smaller settlement with 362 an Islamic cemetery on top. All three sites were excavated by the 363 French-Syrian mission directed by Olivier Rouault and Maria Grazia 364 Masetti-Rouault. Human remains excavated from 1996 to 2006 were 365 studied by Sołtysiak (cf. Sołtysiak \& Bialon, 2013) and are curated in 366 the Department of Bioarchaeology, University of Warsaw, Poland. Ani- 367 mal remains were studied by Anna Grêzak.

Human collagen was extracted from root dentin of second and 369 third permanent molars. For four random skeletons from Tell Masaikh 370 collagen yield was also checked in bone. The source for animal collagen 371 was bone. Human samples were taken from all individuals with at least 372 one root preserved, amounting to a total of 173 specimens covering 373 most of the regional history from the Early Bronze Age until the begin- 374 ning of the 20th century CE. The chronological distribution of human 375 samples is shown in Table 1. To interpret human collagen data against 37ब1 a broader ecological background, faunal material from later occupations 377 at both sites was also included that comprised three dogs, two bovids, 378 
6 WI LEY $\begin{array}{r}\text { Amerian lmanal of } \\ \text { PHYSICAL }\end{array}$

TABLE 1 Chronological distribution of human samples

\begin{tabular}{|c|c|c|c|c|}
\hline Acronym & Period & Dates & M2 samples & M3 samples \\
\hline SHA & Shakkanakku & c. $2300-1900$ BCE & 11 & 7 \\
\hline OB & Old Babylonian & c. $1900-1700$ BCE & 18 & 9 \\
\hline NA & Neo-Assyrian & c. $900-600$ BCE & 4 & \\
\hline CLA & Classical Antiquity & c. $600 \mathrm{BCE}-600 \mathrm{CE}$ & 31 & 25 \\
\hline ISL & Early Islamic & c. $600-1200 \mathrm{CE}$ & 26 & 16 \\
\hline MOD & Modern Islamic & c. $1800-1950$ CE & 15 & 9 \\
\hline Total & & & 105 & 67 \\
\hline
\end{tabular}

one sheep, one goat, three camels, one equid, two gazelles, one fox, and one rodent. They represent later periods of occupation at both sites.

\section{3 | METHODS}

Dentine and bone samples were taken in duplicate. After cleaning the surfaces with aluminium oxide powder air abrasion to remove adhering soil particles, the samples were subjected to a modified Longin method (Brown, Nelson, Vogel, \& Southon, 1988) for collagen extraction, which consists of the following steps: demineralization in $0.5 \mathrm{M} \mathrm{HCl}$ at $2-58 \mathrm{C}$, followed by gelatinization at $728 \mathrm{C}$ for $48 \mathrm{~h}$ in deionized water adjusted to $\mathrm{pH} 3$, with $0.5 \mathrm{M} \mathrm{HCl}$. Insoluble materials of the extraction mix were removed using Ezee filter separators (Elkay Laboratory Products, Basingstoke) and further purified using Amicon Ultra-4 centrifugal filters (Millipore) to remove contaminants lower than 30,000 nominal molecular weight limit (Brown et al., 1988). The filtered products were lyophilized, a subsample of $0.460 .1 \mathrm{mg}$ combusted and analyzed by Isotope Ratio Mass Spectrometry (Finnigan Delta Plus $\mathrm{XL}$ ) in the School of Archaeological Sciences, University of Bradford, UK. The analytical precision of the instrument was estimated as $60.2 \&$ for nitrogen and $60.05 \&$ for carbon isotopes.

At regular intervals, methionine standard reference material, with known $\quad d^{13} \mathrm{C} \quad(-26.6 \&)$ and $d^{15} \mathrm{~N} \quad(-3.0 \&)$ values (Elemental
Microanalysis, Devon, UK) was measured in tandem with samples of 400 bone collagen to determine the accuracy and precision of analytical 401 methods. In addition, internal and external certified laboratory stand- 402 ards (e.g., IAEA standards, bovine liver, fish gel) were used for quality 403 assurance. To control for possible effects of diagenetic processes 404 (Ambrose, 1993), collagen yield, the \%-carbon and \%-nitrogen, and the 405 $\mathrm{C} / \mathrm{N}$ ratio were recorded. Collagen yields of $1 \%$ have been considered 406 sufficient to indicate preservation of authentic collagen (van Klinken, 407 1999), but occasionally in this study samples with lower collagen yield 408 $(>0.2 \%)$ were accepted if a $\mathrm{C} / \mathrm{N}$ ratio was between 2.9 and 3.6, which 409 is the known atomic C: $\mathrm{N}$ range for bone collagen (Ambrose, 1993). 410

Standard parametric and nonparametric statistical tests (Kruskal- 411 Wallis ANOVA with post hoc test, Mann-Whitney $U$ test, Pearson's 412 product-moment correlation coefficient r, Pearson's $v^{2}$ test) have been 413 performed using STATISTICA version 12. Distribution bimodality has 414 been tested using likelihood ratio test for bimodality (Holzmann \& 415 Vollmer, 2008) with a package 'bimodality test' for R (Schwaiger, Holz- 416 mann, \& Vollmer, 2013).

\section{4 | RESULTS}

No collagen could be extracted from four samples of human bone and 419 the collagen yield in dentine was variable between sites and periods 420

TABLE 2 Collagen yield depending on site and chronology

\begin{tabular}{|c|c|c|c|c|c|}
\hline \multirow[b]{2}{*}{ Site } & \multirow[b]{2}{*}{ Chronology } & \multicolumn{2}{|c|}{ Collagen $>0.2 \%$} & \multicolumn{2}{|c|}{ Median coll. yield } \\
\hline & & $\mathrm{n} / \mathrm{N}$ & $(\%)$ & M2 & M3 \\
\hline Tell Ashara & Shakkanakku & $15 / 18$ & $83 \%$ & $10.1 \%$ & $8.9 \%$ \\
\hline Tell Ashara & Old Babylonian & $15 / 19$ & $79 \%$ & $11.2 \%$ & $10.6 \%$ \\
\hline Tell Masaikh & Old Babylonian & $7 / 8$ & $88 \%$ & $5.6 \%$ & $5.5 \%$ \\
\hline Tell Ashara 1 Tell Masaikh & Neo-Assyrian & $3 / 5$ & $60 \%$ & & \\
\hline Tell Masaikh 1 Gebel Mashtale & Classical Antiquity & $35 / 56$ & $63 \%$ & $14.6 \%$ & $13.3 \%$ \\
\hline Tell Masaikh & Early Islamic & $19 / 50$ & $38 \%$ & $15.1 \%$ & $14.2 \%$ \\
\hline Tell Ashara 1 Gebel Mashtale & Modern Islamic & $23 / 24$ & $96 \%$ & $15.3 \%$ & $14.8 \%$ \\
\hline Total (humans) & & $117 / 180$ & $68 \%$ & $13.3 \%$ & $13.5 \%$ \\
\hline Tell Ashara 1 Tell Masaikh & All periods (animals) & $11 / 15$ & $73 \%$ & & \\
\hline
\end{tabular}

Median collagen yield calculated only for teeth where any collagen was preserved. 
TABLE 3 Basic statistics for temporal subsets

\begin{tabular}{|c|c|c|c|c|c|c|c|}
\hline \multirow[b]{2}{*}{ Chronology } & \multirow[b]{2}{*}{$\mathrm{N}$} & \multicolumn{3}{|l|}{$d^{13} C$} & \multicolumn{3}{|l|}{$d^{15} \mathrm{~N}$} \\
\hline & & Mean & SD & Median & Mean & SD & Median \\
\hline SHA & 12 & 219.60 & 0.44 & 219.66 & 14.11 & 2.53 & 14.40 \\
\hline OB (Tell Ashara) & 12 & 219.75 & 0.46 & 219.71 & 14.48 & 2.48 & 14.38 \\
\hline OB (Tell Masaikh) & 5 & 220.20 & 0.15 & 220.24 & 14.43 & 1.43 & 14.36 \\
\hline NA & 3 & 219.21 & 0.54 & 218.93 & 11.89 & 1.78 & 11.03 \\
\hline CLA & 23 & 218.69 & 0.66 & 218.39 & 11.68 & 1.28 & 11.95 \\
\hline ISL & 15 & 219.19 & 0.76 & 219.27 & 12.11 & 1.03 & 12.47 \\
\hline MOD & 15 & 216.44 & 1.81 & 217.12 & 11.96 & 1.29 & 12.37 \\
\hline Total & 85 & 218.77 & 1.48 & 219.04 & 12.71 & 2.02 & 12.68 \\
\hline
\end{tabular}

(Table 2). If the whole number of samples is divided into three broad chronological categories, enough collagen was detected in $82 \%$ of Bronze Age samples from deep strata, in 54\% samples from shallow strata representing Neo-Assyrian to Early Islamic periods and in $96 \%$ of Modern samples. The total average collagen yield for all periods was slightly higher (by $0.5-1.5 \%$ ) for M2 than for M3, perhaps because of the greater average robustness of $\mathrm{M} 2$ roots.

In total, 117 samples representing 85 individuals passed the quality control (collagen yield $>0.2 \%$ with $\mathrm{C} / \mathrm{N}$ ratio between 2.9 and 3.6) (Table 2). For 31 individuals two samples taken from both $\mathrm{M} 2$ and $\mathrm{M} 3$ were measured and there was a high correlation between $d^{13} \mathrm{C}(r \quad 5 \quad .93)$ values and between $d^{15} \mathrm{~N}$ values as well (r 5 .90), and therefore average values were taken for further analyses to represent chronological subsets. The preservation of collagen in animal bone was sufficient in 11 cases representing all taxa except cattle, although most are represented by one individual only. All human and animal individual measurements are available in the Supporting Information Tables 1 and 2, and the basic statistics for temporal subsets are provided in Table 3.

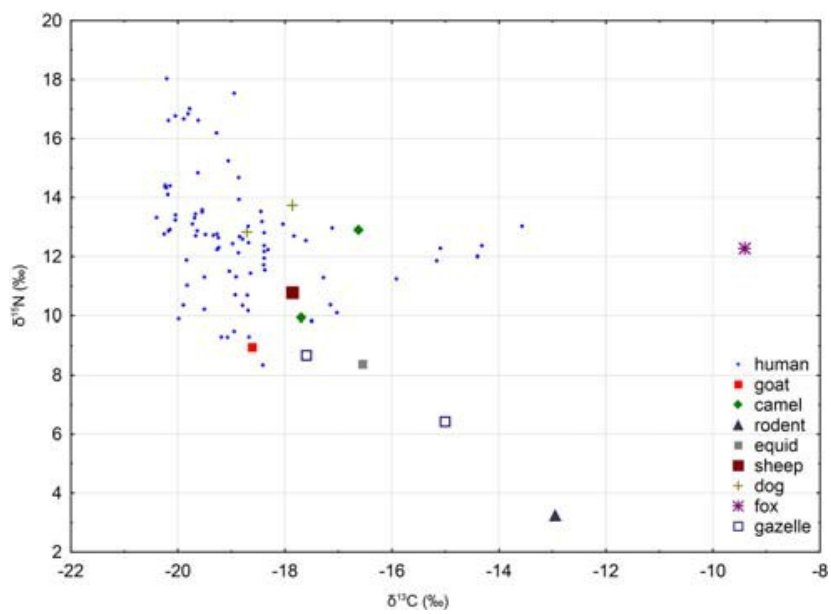

FIGURE 3 Distribution of $d^{13} \mathrm{C}$ and $d^{15} \mathrm{~N}$ values in human and animal samples from the middle Euphrates valley; second and third molars combined

\section{1 | Ecological background}

The distribution of isotopic values for humans is quite broad, and in the 441 case of nitrogen ranges from $8 \&$ to almost $18 \&$. On the other hand, 442 most humans fall within a narrower range of $d^{13} \mathrm{C}$ between 221 and 443 $217 \&$. This supports a diet rich in $C_{3}$ plants, with a limited share of $C_{4} 444$ plants. Faunal isotopic values both in $d^{15} \mathrm{~N}$ and in $\mathrm{d}^{13} \mathrm{C}$ (Figure 3) are $44 \mathrm{FF}$ within the expected trophic level positions, but there is some distinction 446 between domesticated and wild species. Domesticated ungulates (goat, 447 sheep, and camel) and dogs overlap with humans, although in some 448 cases less negative $\mathrm{d}^{13} \mathrm{C}$ can be observed. On the other hand, wild ungu- 449 lates (gazelles and equid) display less negative $d^{13} \mathrm{C}$ and lower $\mathrm{d}^{15} \mathrm{~N}$ val- 450 ues than humans and domestic animals. A rodent with very low $d^{15} \mathrm{~N} 451$ and relatively high $d^{13} \mathrm{C}$, as well as a fox with a very high $\mathrm{d}^{13} \mathrm{C}$ value, fea- 452 ture clearly outside the general isotope value distribution.

\section{2 | Diachronic patterns}

The whole sample was divided into six chronological units covering 455 more than four millennia from c. 2300 BCE to the 20th century CE. 456

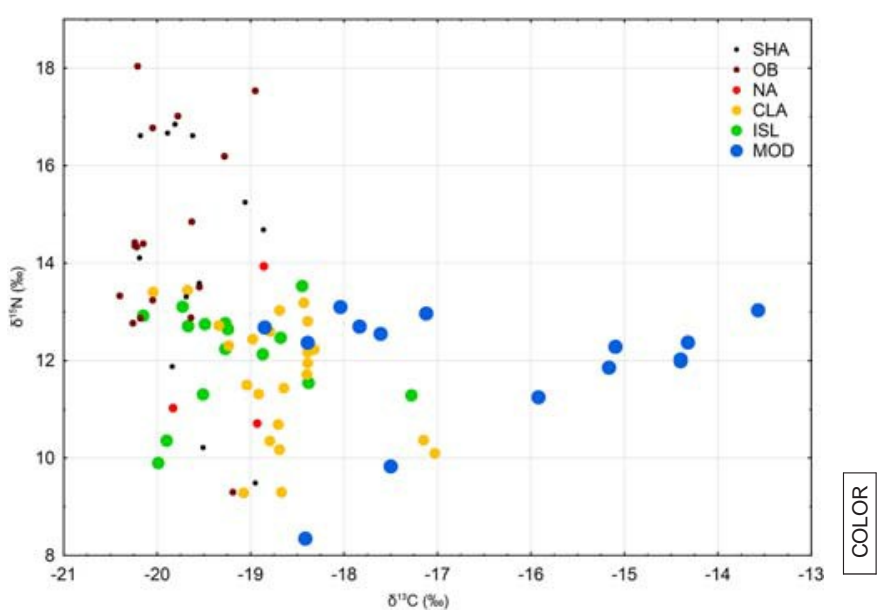

FIGURE 4 Distribution of $\mathrm{d}^{13} \mathrm{C}$ and $\mathrm{d}^{15} \mathrm{~N}$ values in human samples from the middle Euphrates valley; temporal subsets are marked by different dot size and color; second and third molars combined 
(a)

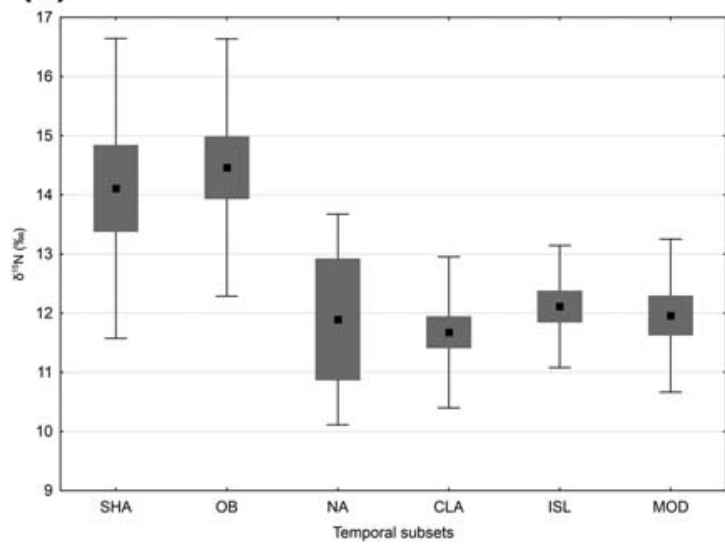

(b)

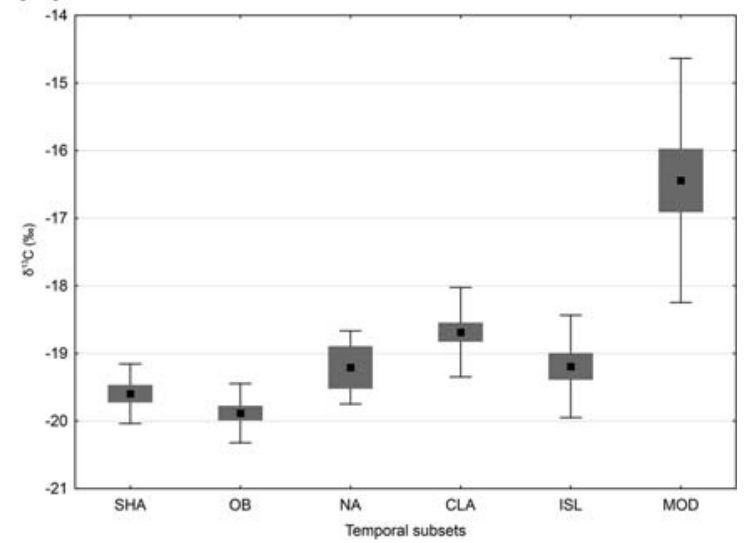

FIGURE 5 Temporal changes in average $\mathrm{d}^{13} \mathrm{C}$ (a) and $\mathrm{d}^{15} \mathrm{~N}$ values (b). The box-and-whisker plots display mean, SE, and SD; second and third molars combined

The number of individuals per subset is variable, but for most periods (except NA) it is $>12$, allowing some insight into temporal trends in $\mathrm{d}^{13} \mathrm{C}$ and $\mathrm{d}^{15} \mathrm{~N}$ values. The data for all temporal subsets are shown in Figure 4, where some differences between subsets may be observed. First of all, SHA and OB distributions overlap in the upper range of the $\mathrm{d}^{15} \mathrm{~N}$ values, while those for all later periods overlap in the lower range of the $\mathrm{d}^{15} \mathrm{~N}$ values. There is also a small shift towards less negative $\mathrm{d}^{13} \mathrm{C}$ values in the later periods, although the difference is much more evident between MOD and all earlier periods. Some individuals from the Modern cemeteries were clearly enriched in ${ }^{13} \mathrm{C}$ and also the range of $\mathrm{d}^{13} \mathrm{C}$ values in this temporal subset is much broader than in the earlier periods, ranging from $219 \&$ to $213.5 \&$.

Temporal differences are statistically significant for both elements (Kruskal-Wallis ANOVA, H 5 53.86, p < .0001 for carbon and H 5 29.30, p <.0001 for nitrogen) and, if NA is excluded for its small sample size, the most significant transition in $\mathrm{d}^{15} \mathrm{~N}$ is between $\mathrm{OB}$ and CLA ( $z^{\prime} 54.50, p<.0002$ ) and for $d^{13} C$ two transitions are observed, again between OB and CLA ( $z^{\prime} 5$ 4.62, p < 0.0001) and between ISL and MOD ( $z^{\prime} 5$ 4.04, $\left.p<.001\right)$. These transitions are well illustrated in 475 Figure $5 \mathrm{~b}$ for nitrogen and in Figure $5 \mathrm{a}$ for carbon.

The discrimination between early (SHA and $\mathrm{OB}$ ) and late subsets 477 in $d^{15} \mathrm{~N}$ values is clear. No late individual has $d^{15} \mathrm{~N}$ values higher 478 than $14 \&$, and only four early individuals have $\mathrm{d}^{15} \mathrm{~N}$ values below $12 \& .479$ Therefore, it may be safely stated that the $d^{15} \mathrm{~N}$ values decreased 480 between the Old Babylonian and the Neo-Assyrian period from 481 approximately $12-17 \&$ to $9-13 \&$. On the other hand, the temporal 482 transitions in the $\mathrm{d}^{13} \mathrm{C}$ values, although no less statistically significant, 483 are less clear (Figure 4). There is an evident bimodal distribution in 484 $\mathrm{d}^{13} \mathrm{C}$ in the Modern subset, within the top cemetery at Tell Ashara. For 485 this subset, the likelihood ratio for bimodality is $4.7(p<.02, N 5$ 13) 486 and the unrestricted estimation of the mean $d^{13} \mathrm{C}$ values in two hypo- 487 thetical subpopulations is 217.96 and $214.73 \&$. Other temporal sub- 488 sets show unimodal distributions of $\mathrm{d}^{13} \mathrm{C}$.

Sex assessment was available for 55 individuals from all periods, 490 but no clear differences between males and females are observed. 491 Interestingly, $\mathrm{d}^{15} \mathrm{~N}$ values of males in the Early Bronze Age deviate 492 (a)

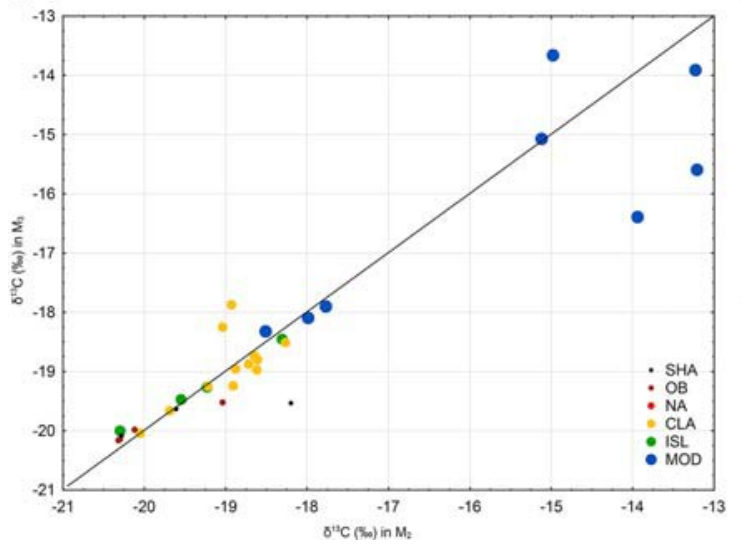

(b)

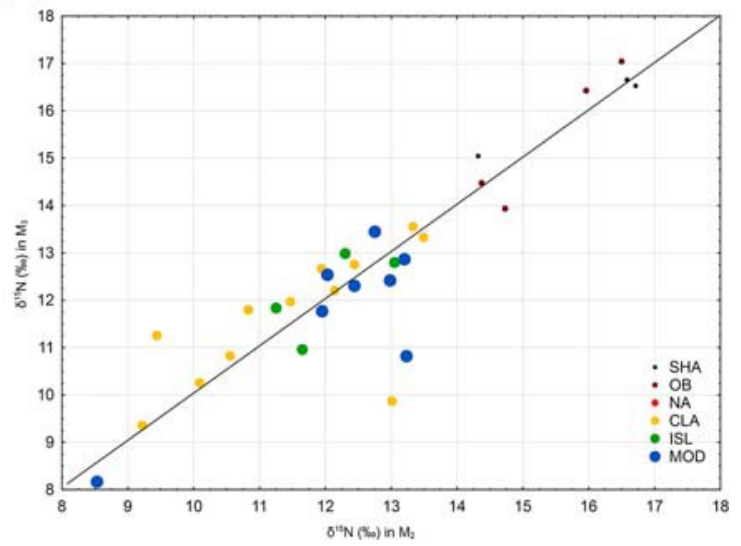

FIGURE 6 Differences between $\mathrm{d}^{13} \mathrm{C}$ (a) and $\mathrm{d}^{15} \mathrm{~N}$ values (b) in second and third molars; temporal subsets marked by different dot size and color 
from a unimodal distribution, and among eight individuals there are three small, yet distinct clusters around 9.5, 12, and 16\&, the last one representing four individuals (cf. Figure 4 and Supporting Information Table 1).

\subsection{Lifetime dietary shifts}

For 31 individuals $d^{13} \mathrm{C}$ and $d^{15} \mathrm{~N}$ values were measured in both $\mathrm{M} 2$ and $\mathrm{M} 3$ and therefore possible dietary shifts between late childhood (10-13 years, M2 root formation time) and adolescence (15-18 years, M3 root formation time) may be detected. Considerable differences between molars in $\mathrm{d}^{13} \mathrm{C}$ values (Figure 6a) occurred in four individuals from the Modern period, in three cases there was a shift towards more negative values (by c. 1-2\&), and in one case towards a less negative value (by c. $1.5 \&$ ). Slighter, but nevertheless evident shifts can be observed in two individuals from Classical Antiquity (c. 1\& towards less negative $d^{13} \mathrm{C}$ ) and in one individual from the Shakkanakku period (c. $1.5 \&$ towards more negative $\mathrm{d}^{13} \mathrm{C}$ ).

The $d^{15} \mathrm{~N}$ values are less correlated between molars, and there are less clear outliers than in the case of carbon isotopes (Figure 6b). Only two individuals dated to Classical Antiquity show a shift in two opposite directions (one c. 13 to c. $10 \&$, the other c. 9.5 to c. $11 \&$ ), and one Modern individual displays a shift from c. 13 to c. $11 \&$.

\section{DISCUSSION}

Although isotopic analyses have contributed widely to the bioarchaeology of various geographical areas and time periods (cf. Lee-Thorp, 2008), they rarely have been adopted in research on human and animal remains from ancient Mesopotamia. This is in part the result of political instability in the region that limited availability of suitable samples at a time when the research on diet became more refined (Sołtysiak, 2006). Climatic conditions of the Near East are also frequently thought to be less favourable for collagen preservation (Bocherens, Mashkour, \& Billiou, 2000; Plug, van der Plicht, \& Akkermans, 2014; Weiner \& BarYosef, 1990). Therefore, the list of sites with any published studies of carbon and nitrogen isotopes so far includes just a few names, for example, Tell Umm el-Marra on the western border of Mesopotamia (Batey, 2011), Tell Barri (Sołtysiak \& Schutkowski, 2015) and Tell Sheh Hamad in the Khabur drainage (H@ring \& Jungklaus, 2010) and finally Tell Bakr Awa in the Shahrizor plain near the Zagros Mountains (Fetner, 2016). Among them, only studies on Tell Barri and on Bakr Awa produced results suitable for diachronic interpretations. In the middle Euphrates valley, while, indeed, the collagen yield in a few analyzed bone samples was very low, most dentin samples retained considerable amount of organic matter and therefore the potential of gathered data is much higher than at other sites in the region.

At a most general level, the diet of people inhabiting the middle Euphrates valley was based mainly on $\mathrm{C}_{3}$ plants, although some $\mathrm{C}_{4}$ resources were also available. Archaeobotanical data are quite limited, but it seems likely that for all periods the most important cultivar was barley, accompanied by much smaller quantities of wheat, millet, lentil and pea. Barley is known to be drought and salt resistant, although its cultivation and consumption was perhaps also a cultural choice 542 (Kubiak-Martens, 2013). Quite important is the limited presence of 543 broomcorn millet, $\mathrm{a} \mathrm{C}_{4}$ cereal, at least since the Neo-Assyrian period 544 (Kubiak-Martens, 2015). However, the most significant source of $C_{4} 545$ biomass may have been the dry steppe, which in the area around the 546 middle Euphrates valley is covered mainly by Artemisia $\left(C_{3}\right)$, Chenopo- 547 diaceae (mainly $\mathrm{C}_{4}$ ) and Poaceae (both $\mathrm{C}_{3}$ and $\mathrm{C}_{4}$ ) (Kubiak-Martens, 548 2013). The distribution of $d^{13} \mathrm{C}$ values in wild animals suggests that 549 ungulates (gazelle, equids) occasionally grazed on $\mathrm{C}_{4}$ plants, and 550 rodents even exhibited a preference for $\mathrm{C}_{4}$ plants, which is clear both 551 from direct and indirect (a fox feeding on rodents) evidence. No direct 552 data from the middle Euphrates valley are available, but rodents living 553 in other arid areas of the Near East feed primarily on chenopods (Kami 554 \& Yadollahvand, 2014; Shenbrot, 2004) and this is consistent with the 555 isotopic signal observed here.

556

The average $d^{15} \mathrm{~N}$ values are high in humans and animals from the 557 middle Euphrates valley and this may be mainly a result of the effect of 558 low precipitation in the region, only c. $140 \mathrm{~mm}$ on average, and the 559 concomitant ${ }^{15} \mathrm{~N}$-enriched diet. Humans living at other sites in North- 560 ern Mesopotamia, located in more humid areas, show a much lower 561 average $d^{15} \mathrm{~N}$, from 6.8\& on average at Bakr Awa on the very humid 562 foothills of the Zagros mountains (Fetner, 2016) to 9.9\& at Tell Barri in 563 the Khabur triangle (Sołtysiak \& Schutkowski, 2015) and 11.1\& at the 564 semi-arid Umm el-Marra site near Aleppo (Batey, 2011).

\section{1 | Shift from intensive to extensive agriculture}

There are at least four factors that may influence the $d^{15} \mathrm{~N}$ values in 567 human tissues. Firstly, the availability of water. The marked differences 568 in average $d^{15} \mathrm{~N}$ values between Mesopotamian sites (see above) are 569 likely the result of differences in average annual precipitation (cf. also 570 Grøcke, Bocherens, \& Mariotti, 1997) and its resulting universal effect 571 on nitrogen values in species consumed by humans. The second factor 572 includes agricultural practices; especially manuring with animal dung 573 may increase $d^{15} \mathrm{~N}$ by more than $6 \&$ in cereals (Fraser et al., 2011). 574 Thirdly, floodplains are enriched in ${ }^{15} \mathrm{~N}$ (Finlay \& Kendall, 2008). The 575 fourth factor relates to the association between $\mathrm{d}^{15} \mathrm{~N}$ and trophic level 576 in that a higher input of animal products in diet is reflected in higher 577 $\mathrm{d}^{15} \mathrm{~N}$ values of the end consumer (Hedges \& Reynard, 2007). 578

The isotopic data from the middle Euphrates valley show a quite 579 clear and consistent picture: there was a shift in $d^{15} \mathrm{~N}$ values between 580 the Old Babylonian period and the Neo-Assyrian period, by c. 22.5\& 581 on average. No sample representing the later periods had $\mathrm{d}^{15} \mathrm{~N}$ above 582 $14 \&$, and in earlier periods the $\mathrm{d}^{15} \mathrm{~N}$ values even reached $18 \&$. On the 583 other hand, several samples representing earlier periods overlapped the 584 range of $d^{15} \mathrm{~N}$ for later periods and three of them even approached the 585 lower limit of $d^{15} \mathrm{~N}$ in the whole dataset. However, the shift between 586 earlier and later periods with no major differences within earlier (i.e., 587 Bronze Age) and later temporal subsets is evident.

For growing urban centres that appeared in the middle Euphrates 589 valley during the Early Bronze Age to control trade traffic along the 590 river, supply of grain was a crucial element of their policy. Although the 591 state of Mari occasionally controlled some dry farming areas in the 592 
Khabur drainage and could import grain using this partially navigable river or from upstream Euphrates valley (Chambon, 2011), maximum possible exploitation of narrow strips of arable land available along the Euphrates was necessitated by high cost and uncertainty of grain supply from more distant parts of Mesopotamia on one side, and growing demands of increasing urban population on the other (cf. van Koppen 2001). In this context, high average $d^{15} \mathrm{~N}$ values during the periods when the state of Mari flourished as the regional power controlling traffic along the Euphrates may be interpreted as evidence of intensive plant cultivation with high levels of manuring

Such interpretation is consistent with the dimorphic model of economy suggested by textual sources (cf. Rowton, 1977). During the growing season of cereals ovicaprid herds grazed in the dry steppe and, after the harvest, cleared the stubble and left their dung on the fields. When arable fields were limited, the area was additionally fertilized using waste from the cities or mud from the river (Wilkinson, 1989).

The situation changed when population density decreased after the decline of local states during the Middle and Late Bronze Age. Intensive plant cultivation was no longer supported by centralized state administration and when large empires took control of the land, their policy supported an increase of the economic potential through extension of arable lands (e.g., by large-scale irrigation) rather than through efforts to increase productivity per hectare. The construction of the Nahr Dawrīn canal may be an example of such policy as it dramatically extended the area of fields suitable for agriculture and secured high cereal yield with no need of intensive manuring. Such large-scale and labor demanding investment is quite consistent with the policy of the Assyrian state, which sought to increase agricultural production after the social collapse in the Early Iron Age (cf. Sołtysiak, 2016) using human resources available through mass deportations (cf. Oded, 1979).

Therefore, the shift in the $\mathrm{d}^{15} \mathrm{~N}$ values between the Bronze Age and the later periods was most likely the effect of changing agricultural policy: from intensive exploitation of limited areas suitable for plant cultivation to more extensive use of land, with lower level of manuring but also with some actions aimed at the increase of available farmlands. A similar transition from more intensive to more extensive agriculture has been observed in the dry farming zone of Northern Mesopotamia and was explained in terms of growing urban population during the Late Chalcolithic and Early Bronze Age (Styring et al., 2017). In the middle Euphrates area, however, this effect was later in time and was even more pronounced because it was triggered by a dramatic re-orientation of subsistence strategies following the collapse of regional independent kingdoms and the establishment of supra-regional empires, rather than by gradual and intrinsic evolution of the local economy.

The results show an interesting threshold in $\mathrm{d}^{15} \mathrm{~N}$ values at around 14\&. Most individuals from the Bronze Age and no individual from later periods have higher $\mathrm{d}^{15} \mathrm{~N}$ values than this threshold, while several Bronze Age samples overlap with this range for later periods, sometimes close to the lower limit of this range (cf. Figure 4). Such an effect is consistent with the proposed interpretation, as during the Bronze Age some grain may have been transported from the north, from areas with much higher average precipitation and therefore lower expected $\mathrm{d}^{15} \mathrm{~N}$ values in imported grain; possible migration of people from the north, feeding on local resources in their adolescence, is also a possibil- 646 ity. Moreover, the level of manuring in intensive agriculture may have 647 varied from time to time and from place to place, and therefore higher 648 variability of $\mathrm{d}^{15} \mathrm{~N}$ values is expected with this kind of subsistence 649 strategy.

\section{2 | Dry steppe exploitation}

As the middle Euphrates valley is located far away from the sea, the 652 most important factor differentiating $\mathrm{d}^{13} \mathrm{C}$ values is the proportion of 653 $\mathrm{C}_{3} / \mathrm{C}_{4}$ plants in the human diet, either directly or indirectly through 654 consumed animals or their products. There are also some minor factors, 655 such as the trophic level spacing (Bocherens \& Drucker, 2003) and cli- 656 matic fluctuations, i.e. differences in precipitation (Riehl, 2008). How- 657 ever, the scope of the trophic level effect is relatively small when 658 compared to differences between $\mathrm{C}_{3}$ and $\mathrm{C}_{4}$ plants (Bocherens \& 659 Drucker, 2003) and in the arid area where any plant cultivation must 660 rely on ground water and not on rain, the climatic effect may be also 661 neglected.

Mesopotamian agriculture was based on $\mathrm{C}_{3}$ crops, especially barley 663 (which was also dominant in the middle Euphrates valley) and wheat 664 (Riehl, 2009), with some share of pulses. The only $C_{4}$ crop present in 665 ancient Mesopotamia was millet, but it always seemed to have been a 666 marginal cultivar, detected in small quantities mainly at Pre-Pottery 667 Neolithic (Hunt et al., 2008) and Neo-Assyrian sites (Nesbitt \& 668 Summers, 1988). It should be noted, however, that broomcorn millet 669 was present in the soil samples from the middle Euphrates valley dated 670 to the Shakkannakku, Neo-Assyrian and Late Roman periods (Kubiak- 671 Martens, 2013). It is therefore possible that this drought resistant $C_{4} 672$ cereal was permanently cultivated in this arid area as an alternative 673 summer crop.

On the other hand, macroremains of some plants present in the 675 dry steppe (e.g., Salsola sp., a $\mathrm{C}_{4}$ chenopod, and the Syrian mesquite, 676

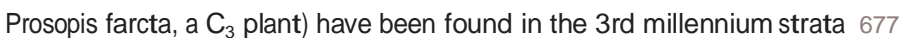
at Tell Ashara, and they most likely derived from animal dung (Kubiak- 678 Martens, 2013). Therefore, use of the dry steppe for pasture may have 679 also increased the $d^{13} \mathrm{C}$ values in ovicaprids and (indirectly) in humans 680 feeding on their meat and dairy products.

Among six temporal subsets analyzed in the present paper, two 682 shifts in $d^{13} \mathrm{C}$ were detected. The first enrichment in ${ }^{13} \mathrm{C}$ by c. $1 \&$ on 683 average occurred between the Old Babylonian and Late Roman peri- 684 ods, with the very small Neo-Assyrian sample in an intermediate posi- 685 tion. Although small, this enrichment is not only statistically significant, 686 but also paralleled by a similar effect observed at two other sites in 687 Northern Mesopotamia: Tell Barri, where the chronology of this small 688 shift is better specified as the transition from the Middle to Late 689 Bronze Age (Sołtysiak \& Schutkowski, 2015) and Bakr Awa, where the 690 dating is even less precise than in the middle Euphrates valley (Fetner, 691 2016). At all these sites the shift was statistically significant and less 692 than 1\& (from 219.43 to $219.07 \&$ on average at Tell Barri, from 693 219.90 to 219.17\& at Bakr Awa and from 219.76 to 218.91\& in 694 the middle Euphrates valley; all early and late subsets except the Mod- 695 ern one) 
At Tell Barri this shift coincided with a dramatic regional decrease in the proportion of pigs among domesticated animals and therefore is was interpreted as the result of greater reliance on ovicaprid grazing in the dry steppe (Sołtysiak \& Schutkowski, 2015). However, at Tell Ashara and Tell Masaikh, a completely different pattern is observed: low quantities of pig remains are present only in bone assemblages from later periods. No samples from the Late Bronze Age were analyzed here and it is not clear whether this enrichment in ${ }^{13} \mathrm{C}$ in the middle Euphrates valley occurred before or after this period. There are therefore two possible explanations of this effect. Either there was a greater share of millet among consumed plants, a possibility that seems to be supported by available archaeobotanical evidence (Kubiak-Martens, 2015). Alternatively, a larger emphasis on cattle and pig husbandry after large-scale irrigation of the Euphrates valley may have pushed ovicaprid herding from more humid zones below the upper terrace to the dry steppes surrounding the settlements and forced animals to graze on pastures with a higher proportion of $\mathrm{C}_{4}$ plants.

A much more pronounced shift in $\mathrm{d}^{13} \mathrm{C}$ values occurred between the Islamic period (i.e., 7th-13th c. CE) and the Modern period (i.e., 19th-20th C. CE). On average, this enrichment in ${ }^{13} \mathrm{C}$ was much higher than the previous one (c. $2.5 \&$ on average), but taking into account the bimodality of $\mathrm{d}^{13} \mathrm{C}$ distribution in the Modern period, the actual enrichment displayed a range of 1.2 and $4.5 \&$ on average, respectively, for two identified modes.

There is an obvious culture-historical explanation of this effect since between these periods a major disruption in the history of Mesopotamia occurred due to invasion of the Mongols and fall of the Caliphate in 1258 (May, 2016). During that time, the agricultural population of Northern Mesopotamia was decimated (Ashtor, 1976) and the area of the middle Euphrates remained very sparsely populated until 17th century when Bedouin tribes from the Arabian Peninsula moved their flocks to the steppes around the valley (Raswan, 1930). In early 20th century, the French authorities settled some farmers from southeastern Anatolia and western Syria in the valley and also forced sedentarization of Bedouins, which however was only partially successful (Velud, 2000)

The cemetery at the top of Tell Ashara belonged to this Bedouin population that based their subsistence on ovicaprid herding both in the river valley and on the dry steppes around. The bimodal distribution may reflect the process of sedentarisation and the difference between individuals that still exercised the nomadic life of sheepherders and those that settled and became sedentary farmers. Also frequent differences in $d^{13} \mathrm{C}$ values between M2 and M3 in this temporal subset, and especially three individuals with $d^{13} \mathrm{C}$ decreasing over time, suggest (small numbers acknowledged) relatively rapid lifetime changes in diet that may be the consequence of this transition from nomadic pastoralism to agriculture or a mixed subsistence strategy.

\subsection{Diet, mobility, and social structure}

Differences in diet between males and females have been proposed for many societies with males often preferring animal-related food rich in proteins and females preferring plant-related food rich in carbohydrates
(Wansink, Cheney, \& Chan, 2003). In the studied sample no such differ- 748 ences were observed and it is likely that the diet of both sexes was 749 similar, at least during childhood and adolescence.

The three-modal distribution of the $d^{15} \mathrm{~N}$ values among eight males 751 from the Shakkanakku and Old Babylonian periods reveals an interest- 752 ing pattern: half of them cluster together above the maximum value for 753 later periods, but there are two data pairs within the $d^{15} \mathrm{~N}$ range for 754 later periods, one close to the maximum limit and one close to the min- 755 imum limit of this range. It is not very likely that such differences were 756 related to diet, but clear differences in average $d^{15} \mathrm{~N}$ values between 757 Tell Ashara/Tell Masaikh, Tell Barri and Bakr Awa suggest that these 758 individuals may have migrated from areas with higher annual precipita- 759 tion (e.g., the dry farming zone north and north-east of the middle 760 Euphrates valley) or consumed large amounts of cereals imported from 761 the north, even though independent corroboration from other isotope 762 systems is not available. During the Early and Middle Bronze Age Tell 763 Ashara-Terqa was one of centers controlling the major trade road along 764 the Euphrates (Liverani, 2014) and therefore high mobility of people 765 living in this place and at that time may be expected.

Although no data about the social status of individuals buried at 767 Tell Ashara and Tell Masaikh are available, the isotopic evidence allows 768 some insight into the social complexity of the middle Euphrates valley. 769 Apart from possible evidence of a transition from mobile to sedentary 770 life in the Modern period (see above), there are also a few other exam- 771 ples of lifetime shifts in $\mathrm{d}^{13} \mathrm{C}$ values; one dated to the Late Roman 772 period indicating a higher share of $\mathrm{C}_{4}$ plants, and one dated to the 773 Shakkanakku period reflecting a shift in the opposite direction. They 774 perhaps witness possible changes from farming to husbandry and 775 inversely, but their low number before the Modern period rather sug- 776 gest stability of subsistence, in spite of textual evidence from the Old 777 Babylonian period reporting movement between the sedentary and 778 mobile segments of the local population (Matthews, 1978). 779

In the Modern subset, apart from the observed bimodality in $\mathrm{d}^{13} \mathrm{C} 780$ values, there are two individuals showing not only relatively low $d^{13} \mathrm{C} 781$ values, but also very low $\mathrm{d}^{15} \mathrm{~N}$ values. It is possible that they were 782 immigrants from more humid regions, relocated to the middle 783 Euphrates valley within the re-settlement program of the early 20th 784 century.

\section{6 - CONCLUSION}

Stable carbon and nitrogen isotope values in dentine of populations 787 inhabiting the region of Tell Ashara-Terqa has produced new data that 788 allow a better understanding of the economic history in this part of 789 Northern Mesopotamia. First of all, as a proxy for prevailing subsist- 790 ence strategies, they provide evidence of a dramatic shift, as witnessed 791 by the clear decrease of average $d^{15} \mathrm{~N}$ values, from more intensive to 792 more extensive plant cultivation between the Old Babylonian and Neo- 793 Assyrian period, an effect most likely related to different agricultural 794 policies in the Bronze Age regional states and in the supra-regional 795 empires following the establishment of the Neo-Assyrian state. 
Temporal shifts in the $d^{13} \mathrm{C}$ values between the Bronze Age and later periods are not easy to interpret and it is equally possible that they were related to a moderately higher share of millet in crops or to more intensive exploitation of dry steppes as pastures. For the Modern period, however, they provide clear evidence of mobile ovicaprid herding in the dry steppe and also evidence of sedentarization of Bedouin tribes at the beginning of the 20th century.

\section{ACKNOW LEDGMENTS}

Many thanks to Maria Grazia Masetti-Rouault and Olivier Rouault for their constant support of the research on human remains at Tell Ashara and Tell Masaikh, to all members of the French archaeological mission excavating these sites, to Anna Grézak for the identification of animal remains used here, and to Andy Gledhill for isotope measurements. The research has been funded by the Polish National Science Centre (Narodowe Centrum Nauki), Grant No. 2012/06/M/ HS3/00272.

\section{REFERENCES}

Ainsworth, W. F. (1888). A personal narrative of the euphrates expedition. London: Kegan Paul, Trench \& Co.

Ambrose, S. H. (1993). Isotopic analysis of paleodiets: Methodological and interpretive considerations. In: Investigations of ancient human tissues: Chemical analyses in anthropology (pp. 1-37). Langhorne: Gordon \& Breach.

Ambrose, S. H., \& DeNiro, M. J. (1987). Bone nitrogen isotope composition and climate. Nature, 325, 201.

Artzy, M., \& Hillel, D. (1988). A defense of the theory of progressive soil salinization in ancient southern Mesopotamia. Geoarchaeology, 3, 235-238.

Ashtor, E. (1976). A social and economic history of the near east in the Middle ages. Berkeley: University of California Press.

Bahhady, F. A. (1981). Recent changes in Bedouin systems of livestock production in the Syrian steppe. In J. G. Galaty, editor. The future of pastoral peoples: Proceedings of a conference held in Nairobi, Kenya, 4-8 August 1980 (pp. 258-266). Ottawa: International Development Research Centre.

Barnett, R. D. (1963). Xenophon and the wall of Media. Journal of Hellenic Studies, 83, 1-26.

Batey, E. K. (2011). Short fieldwork report. Tell Umm el-Marra (Syria), seasons 2000-2006. Bioarchaeology of the Near East, 5, 45-62.

Berthier, S. (2001). Le peuplement rural et les aménagements hydroagricoles dans la moyenne vallée de l'Euphrate entre la fin du VIle et le XIVe siècle. In S. Berthier (Ed.), Peuplement rural et aménagements hydroagricoles dans la moyenne vallẻe de l'Euphrate, fin VIIe-XIXe siècle (pp. 25-264). Damascus: Institut Français de Damas.

Bocherens, H., \& Drucker, D. (2003). Trophic level isotopic enrichment of carbon and nitrogen in bone collagen: Case studies from recent and ancient terrestrial ecosystems. International Journal of Osteoarchaeology, 13, 46-53.

Bocherens, H., Mashkour, M., \& Billiou, D. (2000). Palaeoenvironmental and archaeological implications of isotopic analyses (13C, 15N) from Neolithic to present in Qazvin Plain (Iran). Environmental Archaeology, 5, 1-19.

Bonneterre, D. (1995). The structure of violence in the kingdom of Mari. Canadian Society for Mesopotamian Studies Bulletin, 30, 11-22.
Brown, T. A., Nelson, D. E., Vogel, J. S., \& Southon, J. R. (1988). 851 Improved collagen extraction by a modified Longin method. Radiocar- 852 bon, 30, 171-177.

Chambon, G. (2011). The Mádidum-officials and the trade of grain along 854 the Euphrates. Revue D'Assyriologie Et D'Archẻologie Orientale, 105, 855 193-198.

De Niro, M. J., \& Epstein, S. (1978). Influence of diet on the distribution 857 of carbon isotopes in an animals. Geochimica Et Cosmochimica Acta, 858 42, 495-506.

De Niro, M. J., \& Epstein, S. (1981). Influence of diet on the distribution 860 of nitrogen isotopes in an animals. Geochimica Et Cosmochimica Acta, 861 45, 341-351.

Durand, J.-M. (ed.) (1997). Les documents épistolaires du palais de Mari. 863 Paris: Cerf.

Durand, J.-M. (2002). La maîtrise de l'eau dans les rẻgions centrales du 865 Proche-Orient. Annales Histoire, Sciences Sociales, 57, 561-576. 866

Fetner, R. A. (2016). The impact of climate change on subsistence strat- 867 egies in northern Mesopotamia: The stable isotope analysis and den- 868 tal microwear analysis of human remains from Bakr Awa (Iraqi 869 Kurdistan). Unpublished PhD thesis, University of Warsaw, Poland. 870 http://depotuw.ceon.pl/handle/item/1513

Finlay, J. C., \& Kendall, C. (2008). Stable isotope tracing of temporal and 872 spatial variability in organic matter sources to freshwater ecosystems. 873 In R. Michener \& K. Lajtha (Eds.), Stable isotopes in ecology and envi- 874 ronmental science (pp. 283-333). Oxford: Blackwell Publishing. $\quad 875$

Fleming, D. (2009). Kingship of city and tribe conjoined: Zimri-Lim at 876 Mari. In J. Szuchman (Ed.), Nomads, tribes, and the state in the ancient 877 near east: Cross-discipilinary perspectives. Oriental institute seminars 878 (pp. 227-240). Chicago, IL: Oriental Institute of the University of 879 Chicago.

Fraser, R. A., Bogaard, A., Heaton, T., Charles, M., Jones, G., Christensen, 881 B. T., ... Styring, A. K. (2011). Manuring and stable nitrogen isotope 882 ratios in cereals and pulses: Towards a new archaeobotanical 883 approach to the inference of land use and dietary practices. Journal 884 of Archaeological Science, 38, 2790-2804.

Gawlikowski, M. (1992). Les rivières fantômes du dẻsert oriental. Ktema, 886 17, 169-179.

Genequand, D. (2009). Économie de production, affirmation du pouvoir 888 et dolce vita: Aspects de la politique de l'eau sous les Omeyyades au 889 Bilad al-Sham. In M. Mouton (Ed.), Stratégies d'acquisition de l'eau et 890 sociéte̊ au moyen-orient depuis l'Antiquitê: Études de cas. Bibliothèque 891 archẻologique et historique (pp. 157-177). Beyrouth: Inst. Française du 892 Proche-Orient.

Geyer, B., \& Monchambert, J.-Y. (1987). Prospection de la moyenne 894 vallẻe de l'Euphrate: Rapport prèliminaire: 1982-1985. Mari Annales 895 de Recherches Interdisciplinaires, 5, 293-344.

Geyer, B., \& Monchambert, J.-Y. (2003). La basse vallẻe de l'Euphrate 897 syrien du néolithique ả l'avènement de l'islam. Beyrouth: Institut Fran- 898 çais du Proche-Orient.

Kami, H. G., \& Yadollahvand, R. (2014). A biological study of the little 900 earth hare,Pygeretmus pumilio (Kerr, 1792), in the Golestan Province 901 of Iran (Mammalia: Rodentia: Dipodidae). Poultry, Fisheries \& Wildlife 902 Sciences, 2, e125.

Grezak, A. (2015). Animal bone remains from Terqa and Tell Masaikh. In 904 J. Margueron, O. Rouault, P. Butterlin, \& P. Lombard, editors, Akh 905 Purattim (Vol. 3, pp. 411-422). Lyon: Maison de l'Orient et de la 906 Méditerranée and Ministère des Affaires étrangères et du 907 Développement International.

Grøcke, D. R., Bocherens, H., \& Mariotti, A. (1997). Annual rainfall and 909 nitrogen-isotope correlation in macropod collagen: Application as a 910 
palaeoprecipitation indicator. Earth \& Planetary Science Letters, 153 279-285.

Hedges, R. E. M., \& Reynard, L. M. (2007). Nitrogen isotopes and the trophic level of humans in archaeology. Journal of Archaeological Science, 34, 1240-1251.

Heimpel, W. (2003). Letters to the king of mari: A new translation, with historical introduction, notes, and commentary. Winona Lake, Ind: Eisenbrauns.

Holzmann, H., \& Vollmer, S. (2008). A likelihood ratio test for bimodality in two-component mixtures with application to regional income distribution in the EU. AStA Advances in Statistical Analysis, 92, 57-69.

Hont, O. D. (2005). Techniques et savoirs des communautés rurales: Approche ethnographique du développement. Paris: Karthala.

HGring, H., \& Jungklaus, B. (2010). Der Partisch-R@mische Freidorf von Tall Seh Hamad/Magdala. Teil II: die anthropologische evidenz. Wiesbaden: Harrassowitz Verlag.

Hunt, H. V., Vander Linden, M., Liu, X., Motuzaite-Matuzeviciute, G., Colledge, S., \& Jones, M. K. (2008). Millets across Eurasia: Chronology and context of early records of the genera Panicum and Setaria from archaeological sites in the Old World. Vegetation History \& Archaeobotany, 17, 5-18.

Kassam, Z., \& Robinson, S. E. (2013). Islam and food. In P. B. Thompson \& D. M. Kaplan (Eds.), Encyclopedia of food and agricultural ethics (pp. 1-11). Dordrecht: Springer.

Katzenberg, M. A. (2008). Stable isotope analysis: A tool for studying past diet, demography and life history. In M. A. Katzenberg, \& S. R. Saunders (Eds.), The biological anthropology of human skeletons (2nd ed.) (pp. 413-441). New York: Wiley-Liss.

Klengel, H. (1983). The middle Euphrates and international trade in the Old Babylonian period. Les Annales Archẻologiques Arabes Syriennes, 34, 25-32

van Klinken, G. J. (1999). Bone collagen quality indicators for palaeodietary and radiocarbon measurement. Journal of Archaeological Science, 26, 687-695.

Kubiak-Martens, L. (2013). Plant remains from Tell Ashara (Terqa) and Tell Masaikh in the Middle Euphrates, south-eastern Syria. Archaeobotanical report (field seasons 2009 and 2010). Zaandam: BIAX Consult.

Kubiak-Martens, L. (2015). Plant remains from Tell Ashara (Terqa) and Tell Masaikh in the middle Euphrates, south-eastern Syria. Archaeobotanical report (field seasons 2006 and 2007). In J. Margueron, O. Rouault, P. Butterlin, \& P. Lombard (Eds.), Akh Purattim (Vol. 3, pp. 423-442). Lyon: Maison de l'Orient et de la Méditerranée \& Ministère des Affaires étrangères et du Développement International.

K finne, H. (1995). The Assyrians on the Middle Euphrates and the Habur. In M. Liverani (Ed.), Neo-assyrian geography (pp. 69-85). Rome: Universită di Roma.

KGihne, H., \& Becker, C. (eds). (1991). Die Rezente Umwelt von Tall Beh Hamad und Daten zur Umweltrekonstruktion der assyrischen Stadt Durkatlimmu. Berlin: D. Reimer.

Lafont, B. (2009). Eau, pouvoir et société dans l'Orient ancien: approches théoriques, travaux de terrain et documentation écrite. In M. Al Dbiyat \& M. Mouton (Eds.), Stratégies d'acquisition de l'eau et société au moyen-orient depuis l'Antiquité: études de cas. Bibliothèque archèologique et historique (pp. 11-23). Beyrouth: Inst. Française du Proche-Orient.

Leemans, W. F. (1977). The importance of trade. Some introductory remarks. Iraq, 39, 1-10.

Lee-Thorp, J. A. (2008). On isotopes and old bones. Archaeometry, 50, 925-950.
Lempriere, J. (1836). Bibliotheca classica or a dictionary of all the principal 971 names and terms relating to the geography, topography, history, litera- 972 ture and mythology of antiquity and of the ancients with a chronological 973 table. New York: W.E. Dean.

Liverani, M. (1997). "Half-nomads" on the Middle Euphrates and the con- 975 cept of dimorphic society. Altorientalische Forschungen, 24, 44-48. 976

Liverani, M. (2014). The ancient near east: History, society and economy. 977 London; New York: Routledge/Taylor \& Francis Group.

Lyonnet, B. (2001). L'occupation des marges arides de la Djéziré: Pastor- 979 alisme et nomadisme aux débuts du $3 e$ et du 2e millénaire. Travaux 980 de la Maison de l'Orient méditerranéen, 36, 15-26.

Lyonnet, B. (2009). Who lived in the third-millennium "round cities" of 982 northern Syria? In J. Szuchman (Ed.), Nomads, tribes, and the state in 983 the ancient Near East: Cross-discipilinary perspectives. Oriental Institute 984 seminars (pp. 179-200). Chicago, IL: Oriental Institute of the Univer- 985 sity of Chicago.

Margueron, J. (2004). Mari, métropole de l'Euphrate au Ille et au début du 987 Ile millènaire av. J.-C. Paris: Picard: ERC.

Masetti-Rouault, M. G. (2008). Living in the valley: State, irrigation and 989 colonization in the middle Euphrates valley. In H. KGhne, R. M. 990 Czichon, \& F. J. Kreppner (Eds.), Proceedings of the 4th International 991 Congress of the Archaeology of the Ancient Near East: 29 March-3 992 April 2004, Freie Universität Berlin (Vol. 1, pp. 129-141). Wiesbaden: 993 Harrassowitz.

Masetti-Rouault, M. G. (2010). Rural economy and steppe management in 995 an Assyrian colony in the west. A view from Tell Masaikh, Lower Mid- 996 dle Euphrates, Syria. In H. KGhne (Ed.), Dur-katlimmu 2008 and beyond. 997 Studia chaburensia (pp. 129-149). Wiesbaden: Harrassowitz. 998

Matthews, V. H. (1978). Pastoral nomadism in the mari kingdom (ca. 999 1830-1760 B.C.). Cambridge, MA: American Schools of Oriental 1000 Research.

May, T. (2016). Mongol conquest strategy in the Middle East. In C.1002 Melville \& B. Nicola (Eds.), The mongols' Middle East. Brill (pp. 11-37). 1003

Nesbitt, M., \& Summers, G. D. (1988). Some recent discoveries of millet1004 (Panicum miliaceum L. and Setaria italica (L.) P. Beauv.) at excavations 1005 in Turkey and Iran. Anatolian Studies, 38, 85-97.

1006

Neumann, J., \& Parpola, S. (1987). Climatic change and the 11th-10th1007 century eclipse of Assyria and Babylonia. Journal of Near Eastern1008 Studies, 46, 161-182.

Oded, B. (1979). Mass deportations and deportees in the neo-Assyrian1010 empire. Wiesbaden: Reichert.

1011

Pitard, W. T. (1996). An historical overview of pastoral nomadism in the1012 central Euphrates valley. In J. E. Coleson \& V. H. Matthews (Eds.), Go1013 to the land I will show you. Studies in honor of dwight W. Young (pp.1014 293-308). Winona Lake: Eisenbrauns.

Plug, H., van der Plicht, J., \& Akkermans, P. M. M. G. (2014). Tell Sabi Abyad,1016 Syria: Dating of neolithic cemeteries. Radiocarbon, 56, 543-554. 1017

Raswan, C. R. (1930). Tribal areas and migration lines of the North Ara-1018 bian Bedouins. Geographical Review, 20, 494.

Riehl, S. (2008). Climate and agriculture in the ancient Near East: A syn-1020 thesis of the archaeobotanical and stable carbon isotope evidence.1021 Vegetation History \& Archaeobotany, 17, 43-51.

Riehl, S. (2009). Archaeobotanical evidence for the interrelationship of 1023 agricultural decision-making and climate change in the ancient Near1024 East. Quaternary International, 197, 93-114.

Rosen, S. A., \& Saidel, B. A. (2010). The camel and the tent: An explora-1026 tion of technological change among early pastoralists. Journal of Near1027 Eastern Studies, 69, 63-77.

Rousset, M.-O. (2001). La moyenne vallẻe de l'Euphrate d'après les sour-1029 ces arabes. In S. Berthier (Ed.), Peuplement rural et amẻnagements1030 
hydroagricoles dans la moyenne vallée de l'Euphrate, fin VIIe-XIXe siècle: Région de deir ez zer-abu kemal, syrie (pp. 555-571). Damas: Institut français de Damas.

Rowton, M. (1974). Enclosed nomadism. Journal of the Economic \& Social History of the Orient, 17, 1-30.

Rowton, M. B. (1977). Dimorphic structure and the parasocial element. Journal of Near Eastern Studies, 36, 181-198.

Samuel, D. (2001). Archaeobotanical evidence and analysis. In: Berthier $\mathrm{S}$, editor. Peuplement rural et aménagements hydroagricoles dans la moyenne vallẻe de l'Euphrate, fin VIle-XIXe siècle: Région de deir ez zerabu kemal, syrie (pp. 347-481). Damas: Institut français de Damas.

Schwaiger, F., Holzmann, H., \& Vollmer, S. (2013). Package "bimodalitytest." Marburg: Philipps-Universität Marburg. http://www.uni-marburg.de/fb12/stoch/forschung/rpackages/bimodalitytestwin.zip

Shenbrot, G. (2004). Habitat selection in a seasonally variable environment: Test of the isodar theory with the fat sand rat, Psammomys obesus, in the Negev Desert, Israel. Oikos, 106, 359-365.

Simpson, K. (1984). Archaeological survey in the vicinity of Tall al 'Asharah. Archiv Figr Orientforschung, 31, 185-188.

Sołtysiak, A. (2006). Physical anthropology and the "Sumerian problem." Studies in Historical Anthropology, 4, 145-158.

Sołtysiak, A. (2016). Drought and the fall of Assyria: Quite another story. Climatic Change, 136, 389-394.

Soltysiak, A., \& Bialon, M. (2013). Population history of the middle Euphrates valley: Dental non-metric traits at Tell Ashara, Tell Masaikh and Jebel Mashtale, Syria. Homo: Internationale Zeitschrift Fur Die Vergleichende Forschung Am Menschen, 64, 341-356.

Sołtysiak, A., \& Schutkowski, H. (2015). Continuity and change in subsistence at Tell Barri, NE Syria. Journal of Archaeological Science: Reports, 2, 176-185.

Styring, A. K., Ater, M., Hmimsa, Y., Fraser, R., Miller, H., Neef, R., .. Bogaard, A. (2016). Disentangling the effect of farming practice from aridity on crop stable isotope values: A present-day model from Morocco and its application to early farming sites in the eastern Mediterranean. The Anthropocene Review, 3, 2-22.

Styring, A. K., Charles, M., Fantone, F., Hald, M. M., McMahon, A. Meadow, R. H., ... Bogaard, A. (2017). Isotope evidence for agricultural extensification reveals how the world's first cities were fed. Nature Plants, 3, 17076 van Koppen, F. (2001). The organisation of institutional agriculture in1070 Mari. Journal of the Economic \& Social History of the Orient, 44, 451-1071 504.

Velud, C. (2000). French Mandate policy in the Syrian steppe. In: M.1073 Mundy \& B. Musallam (Eds.), The transformation of nomadic society in 1074 the Arab east (pp. 63-81). Cambridge, UK: Cambridge University1075 Press.

Viollet, P.-L. (2004). L'hydraulique dans les civilisations anciennes: 50001077 ans d'histoire. Paris: Presses de l'Ecole Nationale des Ponts et1078 Chaussęes.

Wansink, B., Cheney, M., \& Chan, N. (2003). Exploring comfort food pref-1080 erences across age and gender. Physiology \& Behavior, 79, 739-747. 1081

Weiner, S., \& Bar-Yosef, O. (1990). States of preservation of bones from 1082 prehistoric sites in the Near East: A survey. Journal of Archaeological1083 Science, 17, 187-196.

Wilkinson, T. J. (1989). Extensive sherd scatters and land use intensity:1085 Some recent results. Journal of Field Archaeology, 16, 31-46.

1086

Wilkinson, T. J. (1997). Environmental fluctuations, agricultural produc-1087 tion and collapse: A view from Bronze Age Upper Mesopotamia. In1088 H. N. Dalfes, G. Kukla, H. Weiss (Eds.), Third millennium BC climate1089 change and old world collapse (pp. 67-106). Berlin, Heidelberg:1090 Springer.

1091

Zawadzki, S. (2008). The middle Euphrates in the first millennium B.C. as 1092 an intermediary in economic contacts between Mesopotamia and the1093 West. Palamedes, 3, 35-48.

\section{SUPPORTING INFORMATION}

Additional Supporting Information may be found online in the sup-1096 porting information tab for this article.

How to cite this article: Sołtysiak A, Schutkowski H. Stable iso- 1101 topic evidence for land use patterns in the Middle Euphrates 1102 Valley, Syria. Am J Phys Anthropol. 2018;00:1-14. https:// do 1103 i. 